\title{
A Low Harmonic Drive System using ZSI for a Variable Speed Wind Turbine
}

\author{
F. Max Savio ${ }^{\# 1}$

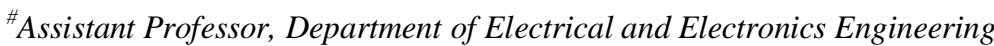 \\ Jeppiaar Institute of Technology, Chennai.
}

\begin{abstract}
In this paper, a Stand-Alone Induction Motor drive is controlled using an Impedance Source Inverter (ZSI). The Permanent Magnet Synchronous Generator (PMSG) is used as the variable speed wind turbine generator for the power generation. The Space Vector Pulse Width Modulation (SVPWM) controls the ZSI switches for generating constant voltage supply for driving the Induction Motor. In the proposed paper, the generator side diode rectifier and the load side ZSI is presented. The variable speed generator is modeled with the mathematical modeling of the PMSG machine equations. The performance of the PMSG obtained is efficient for a drive system. The PMSG designed for a power rating of $4 \mathrm{~kW}$. The ZSI eliminates the shoot-through problem and the SVM controlled switching reduces the harmonic contents for a drive application. The performance of the proposed design is verified in the results obtained. The results are generated using the MATLAB 7.
\end{abstract}

Keywords - Permanent Magnet Synchronous Generator (PMSG), Space Vector Pulse Width Modulation (SVPWM), Impedance Source Inverter (ZSI), Stand-Alone Wind Energy Conversion System (SAWECS), Rectifier, MATLAB/SIMULINK.

\section{INTRODUCTION}

Years of research has proved that the renewable energy is the most effective and environmental friendly source compared to the non-renewable energy under practice. The environmental friendly refers to the non-polluting energy conversion from the natural available sources. The wind source available is a renewable source which is converter to electric energy by the wind turbine system. The wind turbines are considered to be the generators that convert the mechanical power to electric power. The turbines are of different types classified as variable and fixed speed turbines. The variable speed turbines converts the variable wind speed to a constant electric power by means of the power electronic circuits. The variable speed wind turbine is used which is more effective than fixed speed wind turbines. The Permanent Magnet Synchronous Generator (PMSG) [19] is used as the variable speed wind turbine. In the proposed work, the variable speed wind turbine is used to power an Induction motor drive system through an effective power electronic circuit. The Impedance Source inverter (ZSI) [8] is an effective AC-DC-AC converter circuit. The effect of impedance source produces increased efficiency as the zero state switching of an inverter is eliminated. The design of the impedance source inverter is explained.

In this power generation system, the PMSG Wind turbine is connected to the Impedance Source Inverter. The AC output from the PMSG is converted to DC by means of diode rectifier. The output of the rectifier serves as the input power to the ZSI. The inverter is controlled using the Space Vector Pulse Width Modulation (SVPWM) technique. The SVPWM is most effective as it produce a low harmonic output. With reduced THD level, the efficiency increases. The circuit model is shown in the Figure 1.

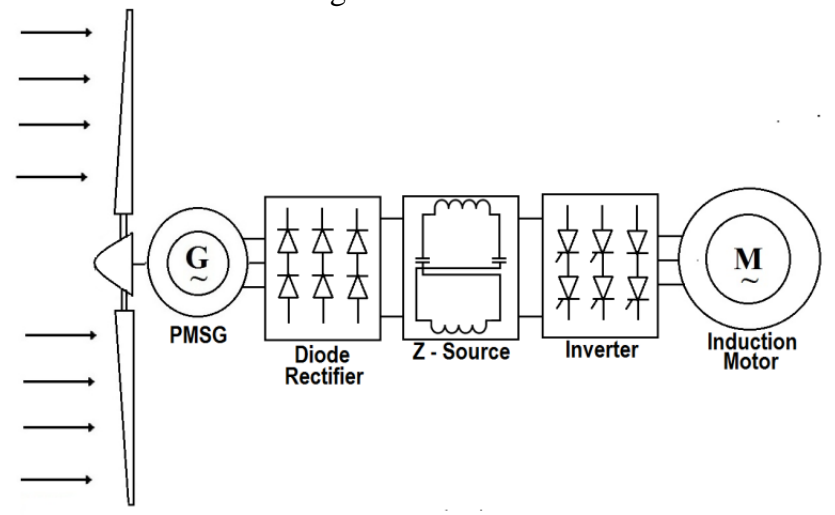

Figure 1: Block diagram of the Proposed System

The variable speed wind turbine, eliminates the use of gear box setup which is used in other conventional wind turbines. This is one of the major advantages as it reduces the cost of the system.

\section{DyNAMIC MOdel OF PMSG}

The mathematical modeling of the Permanent Magnet Synchronous Generator (PMSG) [19] is modeled from the machine equations obtained for the voltage vector coordinates in terms of current and flux. The equation is given as,

$$
\begin{aligned}
& V_{a}=i_{a} R_{s}+p \varphi_{a} \\
& V_{b}=i_{b} R_{g}+p \varphi_{b} \\
& V_{u}=i_{a} R_{a}+p \varphi_{u}
\end{aligned}
$$

Where, $p=\frac{d}{d t}, i_{a} \cdot i_{b}$ and $i_{c}$ are the phase currents, $\varphi_{a}, p_{b}$ and $\varphi_{\mathrm{c}}$ are the flux developed by the phase currents and $R_{g}$ is the stator resistance.

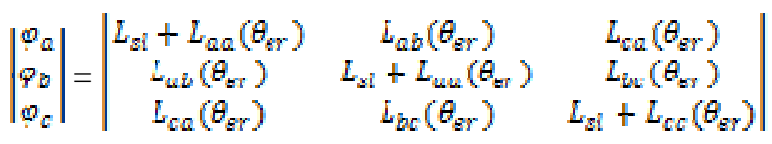




$$
\left|\begin{array}{l}
i_{u} \\
i_{b} \\
i_{s}
\end{array}\right|+\left[\begin{array}{l}
\varphi_{P M a}\left(\theta_{s r}\right) \\
\varphi_{P M b}\left(\theta_{s r}\right) \\
\varphi_{M M d}\left(\theta_{s}\right)
\end{array} \mid\right.
$$

Where, $\theta_{c r}$ is the rotor PM axis angle to a axis / electrical angle.

The IPM rotor machines, the distributed winding equations are derived from the value of $\theta_{\mathrm{er}}$ which is considered as selfinductance and mutual inductance which mainly depend on it. But the stator inductance is invariant for the surface PM Pole rotors. The existence of slot openings serves as additional factor depending on the stator inductance on $\mathbb{N}_{3} \theta_{\mathrm{er}}$. However, the rotor pole configurations are considered that the stator self and mutual inductance are similar catheterized for the concentrated windings. Contradictorily, the distributed windings are larger in values. However, the concentrated windings have smaller end-turn leakage inductance. The space harmonics are also one of the factors to be considered in the fluxes of the permanent magnet machines.

Therefore, with this fact the modeling of the machine takes the assumption that, self and the mutual inductance are either constant or vary sinusoidally with the rotor position $\left(2 \theta_{\mathrm{fy}}\right)$. In general, the flux linkages $\varphi_{\mathrm{pMa}}\left(\theta_{\mathrm{er}}\right)$ variation in the stator phases are sinusoidal but with $\theta_{\mathrm{s}}$. Eventual the time pulsation in the torque and current are observed due to harmonics in the $\mathrm{d}-\mathrm{q}$ model for the $\omega_{1}=\omega_{2}$ :

$$
\begin{aligned}
& \| L_{a b} \theta_{s \Gamma} \mid=
\end{aligned}
$$

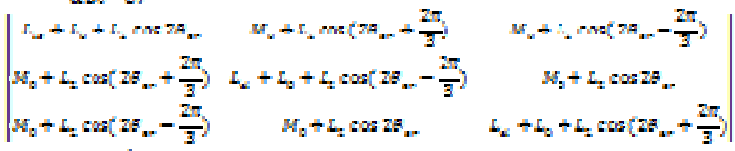

$$
\begin{aligned}
& M=-\frac{c_{\mathbb{g}}}{2} \text { for distributed windings }
\end{aligned}
$$

Thus the matrix form of the phasor coordinates are given as,

$$
\begin{aligned}
& \left\|i_{a, b d}\right\| R_{g}|-| V_{a, b, s} \mid=-\frac{d\left|\phi_{a, z}\right|}{d t}
\end{aligned}
$$

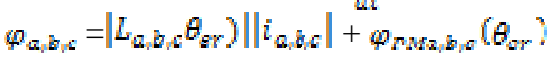

The Park's transformation from stator to rotor coordinates are given as in the Figure 2 are expressed as,

$$
\begin{aligned}
& \left|\begin{array}{l}
i_{d} \\
i_{q} \\
i_{0}
\end{array}\right|=\left|P\left(\theta_{a r}\right)\right|\left[\begin{array}{l}
i_{a} \\
i_{b} \\
i_{q}
\end{array} \mid\right.
\end{aligned}
$$

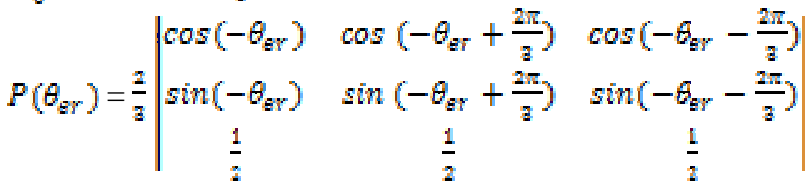

The same transformations are valid for $\varphi_{d q 0}, V_{s i n} n$.

Finally, for sinusoidal $\varphi_{P M a, b, e}\left(\theta_{s,}\right)$ distributions,

$$
\begin{aligned}
& i_{d} R_{z}-V_{d}=L_{d} \frac{d i_{d}}{d t}+\omega_{r} L_{q} i_{q} \\
& i_{q} R_{s}-V_{q}=-L_{q} \frac{\omega_{q}}{d t}-\omega_{Y}\left(L_{d} i_{d}+\varphi_{F M 1}\right)
\end{aligned}
$$

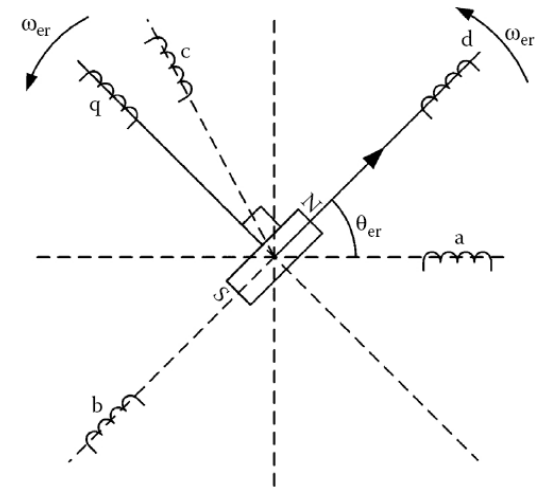

Figure 2: Three Phase d-q transformation

With

$$
\overline{\varphi_{s}}=\varphi_{d}+j \varphi_{q} ;=\varphi_{d}=\varphi_{M M 1}+L_{q} i_{d} ; \varphi_{q}=L_{q} i_{q}
$$$$
\bar{V}=V_{u}+j V_{4} ; \bar{z}_{i}=i_{u}+j i_{4}
$$

From the above equations the space-vector model of the PMSG is obtained as,

$$
\begin{aligned}
& \overline{i_{s}}-V_{s}=-\frac{d \phi_{s}}{d t}-j \omega_{\mathrm{r}} \overline{\phi_{s}} \\
& T_{e}=p_{1} \frac{p_{q}}{z_{q}}=\frac{i}{2} p_{1}\left(\varphi_{F M 1}+\left(L_{d}-L_{q}\right) i_{d}\right) i_{q} \\
& L_{d}=L_{s i}+\frac{3}{2}\left(L_{0}-\left|L_{2}\right|\right) ; L_{q}=L_{s l}+\frac{3}{2}\left(L_{0}+\left|L_{2}\right|\right)
\end{aligned}
$$

From the derived expressions the d-q equivalent circuit of the PMSG is given as in the Figure 3.

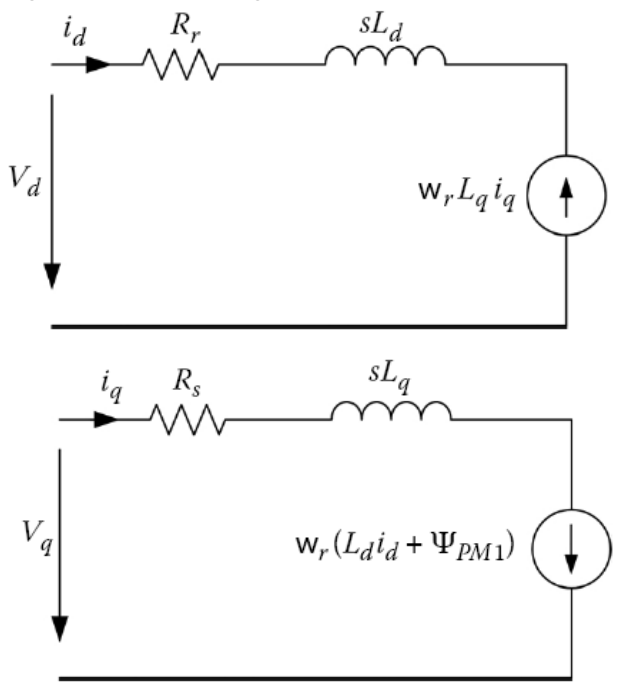

Figure 3: d-q equivalent circuit of PMSG

The figure 5 shows the vector representation of the PMSG. The torque value is in negative because of the current $i_{\theta}$ which is negative. Under steady state condition, the phase voltages are given as, 


$$
V_{a b s}=V_{1} \sqrt{2} \cos \left(\omega_{r} t-(i-1) \frac{i \pi}{i}\right)
$$

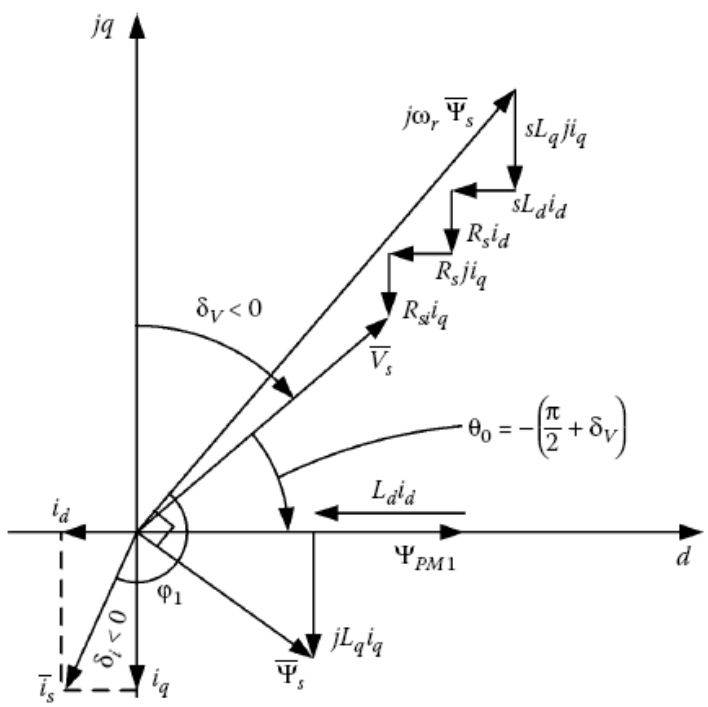

Figure 4: Vector Representation of PMSG

\section{MOdELING OF IMPEDANCE SOURCE INVERTER}

A Z-source inverter [8] is similar to an inverter with singlestage topology. The inverter in general operates and produces low output due to buck operation. The ZSI here with single stage operates both at buck and boost operation. The limitation of having zero stage in inverter switching is eliminated by the impedance source connected at the input level. The zero inactive state occurs when the switches of the same leg turns on at the same time during the operation. This however produces zero voltage at the output thus producing the less efficient output. The Impedance which has one input and one output port so referred as two port network. This network also called as lattice network. Lattice network is the one of the common four terminal two port network.

The lattice network is used in filter sections and is also used as attenuators. Lattice networks are sometimes used in preference to ladder structure in some special applications. This lattice network, $\mathrm{L}_{1}$ and $\mathrm{L}_{2}$ are series arms inductances, $\mathrm{C}_{1}$ and $\mathrm{C}_{2}$ are diagonal capacitances. This is a two port network that consists of split inductors $\mathrm{L}_{1}$ and $\mathrm{L}_{2}$ and capacitors $\mathrm{C}_{1}$ and $\mathrm{C}_{2}$ connected in $\mathrm{X}$-shape. The impedance source inverter bridge has one extra zero state. When the load terminals are shorted through both upper and lower devices of any one phase leg or all three phase legs this shoot through zero state is forbidden in the VSI, because it would cause a shootthrough fault. This network makes the shoot through zero state possible. This state provides the unique buck-boost [17] feature to the inverter. The equivalent circuit of the Impedance Source Inverter is shown in Figure 5. The inverter bridge is equivalent to a short circuit when the inverter bridge is in the shoot-through zero state. The equivalent switching frequency from the impedance source network is six times the switching frequency of the main inverter, which greatly reduces the required inductance of the impedance source network.

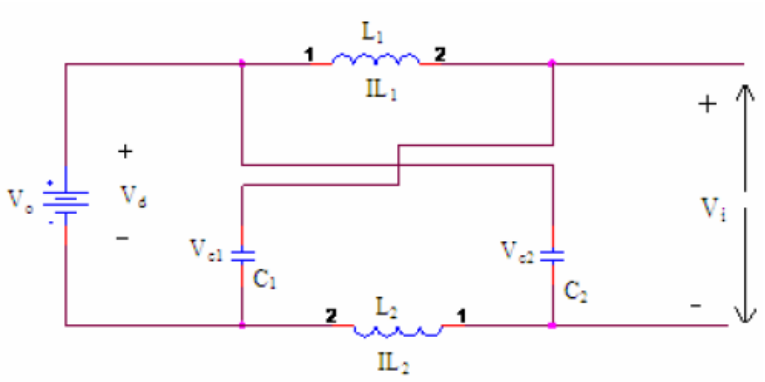

Figure 5: Equivalent Circuit of ZSI

\section{A. Mathematical Modelling of ZSI}

The three phase Z-source inverter fed load system is shown in Figure 6. This type of inverter has a lattice network or impedance network on its DC side, which connects the source to the inverter. The two inductors and two capacitors are used to provide buck and boost operation.

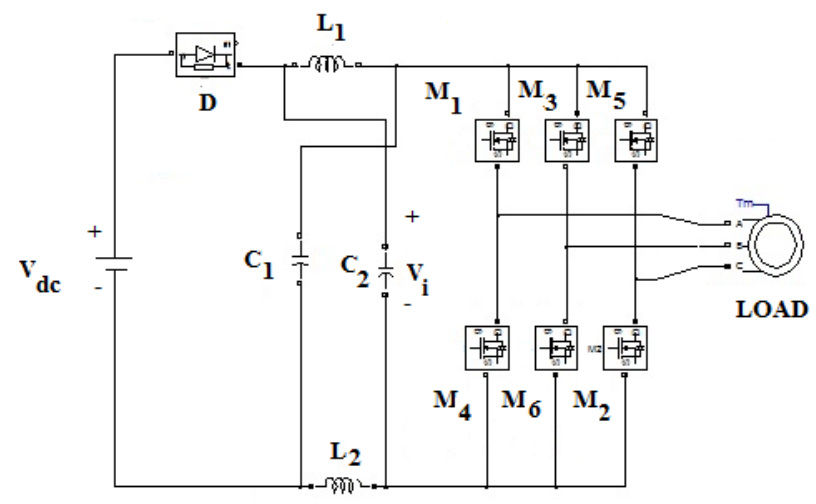

Figure 6: Impedance Source Inverter (ZSI)

Assume the inductors $\left(\mathrm{L}_{1}\right.$ and $\left.\mathrm{L}_{2}\right)$ and capacitors $\left(\mathrm{C}_{1}\right.$ and $\left.\mathrm{C}_{2}\right)$ have the same inductance and capacitance values respectively. $\mathrm{L}_{1}$ and $\mathrm{L}_{2}-$ series arm inductors; $\mathrm{V}_{\mathrm{dc}}$ is input voltage;

$\mathrm{C}_{1}$ and $\mathrm{C}_{2}$ - parallel arm capacitors; $\mathrm{V}_{\mathrm{i}}$ is output voltage;

$\mathrm{V}_{\mathrm{c} 1}=\mathrm{V}_{\mathrm{c} 2}=\mathrm{V}_{\mathrm{c}}$

$\mathrm{V}_{\mathrm{L} 1}=\mathrm{V}_{\mathrm{L} 2}=\mathrm{V}_{\mathrm{L}}$

$\mathrm{V}_{\mathrm{L}}=\mathrm{V}_{\mathrm{c}}$

$\mathrm{V}_{\mathrm{D}}=2 \mathrm{~V}_{\mathrm{c}}$

$\mathrm{V}_{\mathrm{i}}=0$

During the switching cycle $\mathrm{T}$

$\mathrm{V}_{\mathrm{L}}=\mathrm{V}_{0}-\mathrm{V}_{\mathrm{c}}$

$\mathrm{V}_{\mathrm{D}}=\mathrm{V}_{0}$

$\mathrm{V}_{\mathrm{i}}=\mathrm{V}_{\mathrm{c}}-\mathrm{V}_{\mathrm{L}}=2 \mathrm{~V}_{\mathrm{c}}-\mathrm{V}_{\mathrm{o}}$

$\mathrm{V}_{\mathrm{i}}=2 \mathrm{~V}_{\mathrm{c}}-\mathrm{V}_{0}$

Where $\mathrm{V}_{0}$ is the DC source voltage and

$\mathrm{T}=\mathrm{T}_{0}+\mathrm{T}_{1}$

The average voltage of the inductors over one switching period ( $\mathrm{T}$ ) should be zero in steady state,

$\mathrm{V}_{\mathrm{L}}=\mathrm{V}_{\mathrm{L}}=\mathrm{T}_{0} * \mathrm{~V}_{\mathrm{c}}+\mathrm{T}_{1}\left(\mathrm{~V}_{0^{-}} \mathrm{V}_{\mathrm{c}}\right) / \mathrm{T}=0$

$\mathrm{V}_{\mathrm{L}}=\left(\mathrm{T}_{0} * \mathrm{~V}_{\mathrm{c}}+\mathrm{V}_{0} * \mathrm{~T}_{1}-\mathrm{V}_{\mathrm{c}} * \mathrm{~T}_{1}\right) / \mathrm{T}=0$

$\mathrm{V}_{\mathrm{L}}=\left(\mathrm{T}_{0}-\mathrm{T}_{1}\right) \mathrm{V}_{\mathrm{C}} / \mathrm{T}+\left(\mathrm{T}_{1} * \mathrm{~V}_{0}\right) / \mathrm{T}$

$\mathrm{V}_{\mathrm{c}} / \mathrm{V}_{0}=\mathrm{T}_{1} /\left(\mathrm{T}_{1}-\mathrm{T}_{0}\right)$ 
Similarly the average DC link voltage across the inverter bridge can be found as,

$\mathrm{V}_{\mathrm{i}}=\left(\mathrm{T}_{0} * 0+\mathrm{T}_{1}\right) *\left(2 \mathrm{~V}_{\mathrm{c}}-\mathrm{V}_{0}\right) / \mathrm{T}$

$\mathrm{V}_{\mathrm{i}}=\left(2 \mathrm{~V}_{\mathrm{c}} \cdot \mathrm{T}_{1} / \mathrm{T}\right)-\left(\mathrm{T}_{1} \mathrm{~V}_{0} / \mathrm{T}\right)$

$2 \mathrm{~V}_{\mathrm{c}}=\mathrm{V}_{0}$

From the above equations,

$\mathrm{T}_{1} * \mathrm{~V}_{0} /\left(\mathrm{T}_{1}-\mathrm{T}_{0}\right)=2 \mathrm{~V}_{\mathrm{c}} * \mathrm{~T}_{1} /\left(\mathrm{T}_{1}-\mathrm{T}_{0}\right)$

$\mathrm{V}_{\mathrm{c}}=\mathrm{V}_{0} * \mathrm{~T}_{1} /\left(\mathrm{T}_{1}-\mathrm{T}_{0}\right)$

The peak DC link voltage across the inverter bridge is

$\mathrm{V}_{\mathrm{i}}=\mathrm{V}_{\mathrm{c}}-\mathrm{V}_{\mathrm{L}}=2 \mathrm{~V}_{\mathrm{c}}-\mathrm{V}_{0}$

$=\mathrm{T} /\left(\mathrm{T}_{1}-\mathrm{T}_{0}\right) \cdot \mathrm{V}_{0}=\mathrm{B} * \mathrm{~V}_{\mathrm{o}}$

Where $\mathrm{B}=\mathrm{T} /\left(\mathrm{T}_{1}-\mathrm{T}_{0}\right)$ i.e $\geq 1$

$\mathrm{B}$ is a boost factor

\section{MODELING OF SVPWM}

Space vector modulation (SVM) [8] is an algorithm for the control of pulse width modulation (PWM). It is used for the creation of alternating waveform (AC) waveform. It most commonly used in inverters, 3 phase ac powered motors. There are various types of SVM that result in different quality and computational requirements. One active area of development is in the reduction of total harmonic distortion (THD) created by the rapid switching inherent to these algorithms. With the increase of levels, traditional approaches of SVM based on five-level or seven level inverters are hardly realized. Some modified methods have been proposed to approach the SVM of inverter with any levels. One of them is carrying out the SVM in 60-degree coordinates. This section will outline this SVM scheme. Any three-phase system (defined by $\mathrm{a}_{\mathrm{x}}(\mathrm{t}), \mathrm{a}_{\mathrm{y}}(\mathrm{t}) \mathrm{a}_{\mathrm{z}}(\mathrm{t})$ ) can be represented uniquely by a rotating vector as ,

$a_{g}=\frac{2}{3}\left[a_{x}(t)+a_{1} a_{y}(t)+a^{2} \cdot a_{z}(t)\right]$

Given a three-phase system, the vector representation is achieved by the following $3 / 2$ transformation:

$\left[\begin{array}{l}A_{\alpha} \\ A_{\beta}\end{array}\right]=\frac{2}{2} \cdot\left[\begin{array}{ccc}1 & \frac{-1}{2} & \frac{-1}{2} \\ 0 & \frac{\sqrt{z}}{2} & \frac{-\sqrt{z}}{2}\end{array}\right] \cdot\left[\begin{array}{l}\mathrm{a}_{\mathrm{X}} \\ \mathrm{a}_{\mathrm{Y}} \\ \mathrm{a}_{\mathrm{z}}\end{array}\right]$

Where $(\mathrm{A} \alpha, \mathrm{A} \beta)$ are forming an orthogonal 2-phase system and $\mathrm{a}_{\mathrm{S}}=\mathrm{A}_{\alpha}+\mathrm{j} \mathrm{A}_{\beta}$. A vector can be uniquely defined in the complex plane by these components. The reverse transformation (2/3 Transformation) is given by,

$\left\{\begin{array}{l}\mathrm{ax}_{\mathrm{y}}(\mathrm{t})=\operatorname{Re}\left[\mathrm{a}_{3}\right]+\mathrm{a}_{0}(\mathrm{t}) \\ \mathrm{ay}_{\mathrm{y}}(\mathrm{t})=\operatorname{Re}\left[\mathrm{a}^{2}, \mathrm{a}_{3}\right]+\mathrm{a}_{0}(\mathrm{t}) \\ \mathrm{a}_{\mathrm{z}}(\mathrm{t})=\operatorname{Re}\left[\mathrm{a}_{1} \mathrm{a}_{3}\right]+\mathrm{a}_{0}(\mathrm{t})\end{array}\right.$
$\mathrm{a}_{0}=\frac{1}{3} \cdot\left[\mathrm{ax}_{\mathrm{X}}(\mathrm{t})+\mathrm{ay}_{\mathrm{Y}}(\mathrm{t})+\mathrm{az}_{\mathrm{Z}}(\mathrm{t})\right]$

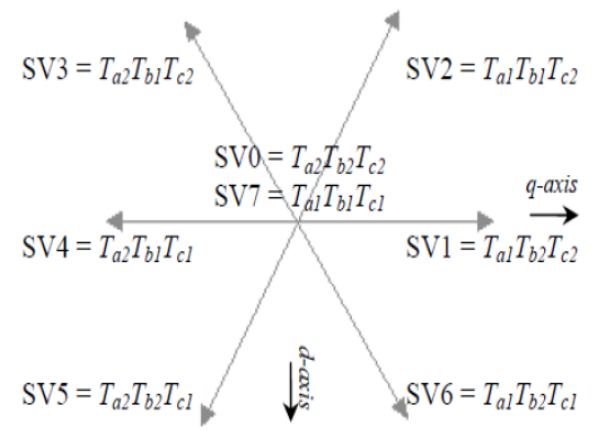

Figure 7: Space vector d,q-axis locations and their corresponding closed switches

It represents the homopolar component. It results a unique correspondence between a Space Vector in the complex plane and a three-phase system. The method of choosing active vectors is the same regardless of which SVM algorithm is used. The Space Vector representation is shown as in Figure 7.

\section{Simulation And Results}

The simulation is based on the mathematical modeling of the PMSG connected to the Impedance Source Inverter (ZSI) and the Induction Motor (IM). The IM is modeled for the mechanical output of 5HP. The modeling is the Matlab coding which uses the machine variables for the machine equations.

TABLE I

SYSTEM PARAMETERS

\begin{tabular}{|c|l|l|}
\hline \multirow{2}{*}{ S. N } & \multicolumn{2}{|c|}{ Simulation and Modeling Parameters } \\
\cline { 2 - 3 } & \multicolumn{1}{|c|}{ Parameter } & \multicolumn{1}{c|}{ Value } \\
\hline 1 & Cut-in Wind Speed & $4 \mathrm{~m} / \mathrm{s}$ \\
\hline 2 & Rated Wind Speed & $12 \mathrm{~m} / \mathrm{s}$ \\
\hline 3 & PMSG Power & $4 \mathrm{~kW}$ \\
\hline 4 & PMSG Frequency & $50 \mathrm{~Hz}$ \\
\hline 5 & PMSG no. of Poles & 4 \\
\hline 6 & PMSG Winding Resistance & $1.4 \Omega$ \\
\hline 7 & PMSG Winding Inductance & $5.7 \mathrm{mH}$ \\
\hline 8 & Z - Source Impedance & $150 \mathrm{mH}$ \\
\hline 9 & Z - Source Capacitance & $1500 \mu \mathrm{F}$ \\
\hline 10 & Switching Frequency & $5 \mathrm{kHz}$ \\
\hline 11 & IM Rated Voltage & $400 \mathrm{~V}$ \\
\hline 12 & IM Rated Current & $9 \mathrm{~A}$ \\
\hline 13 & IM Rated Speed & $1500 \mathrm{rpm}$ \\
\hline 14 & IM Mechanical Power & $5 \mathrm{HP}$ \\
\hline
\end{tabular}

The simulation is performed for the designed values and the results are shown. The PMSG output with respect to the time is shown in the figure 8 . The PMSG output voltage and current are $320 \mathrm{~V}$ and $8 \mathrm{~A}$ respectively. The Output Power is $4060 \mathrm{~W}$ developed by the rotor speed and torque is $2156 \mathrm{rpm}$ and $78.2 \mathrm{~N}-\mathrm{m}$ respectively. 


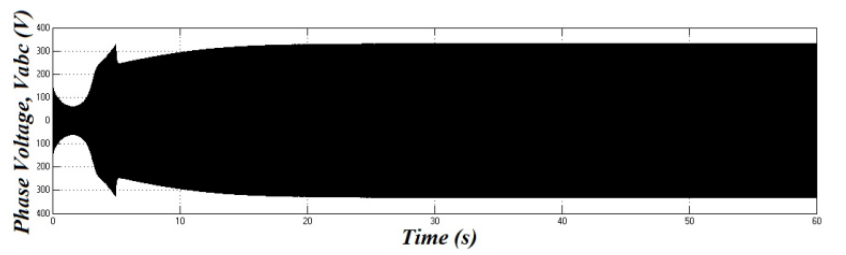

The ZSI with the SVM technique is effective to drive the load at a lower harmonic level. For a drive system, the harmonics are the deciding factor for the efficiency of the system. The work performed with the drive application is observed to have the THD of $3.66 \%$.
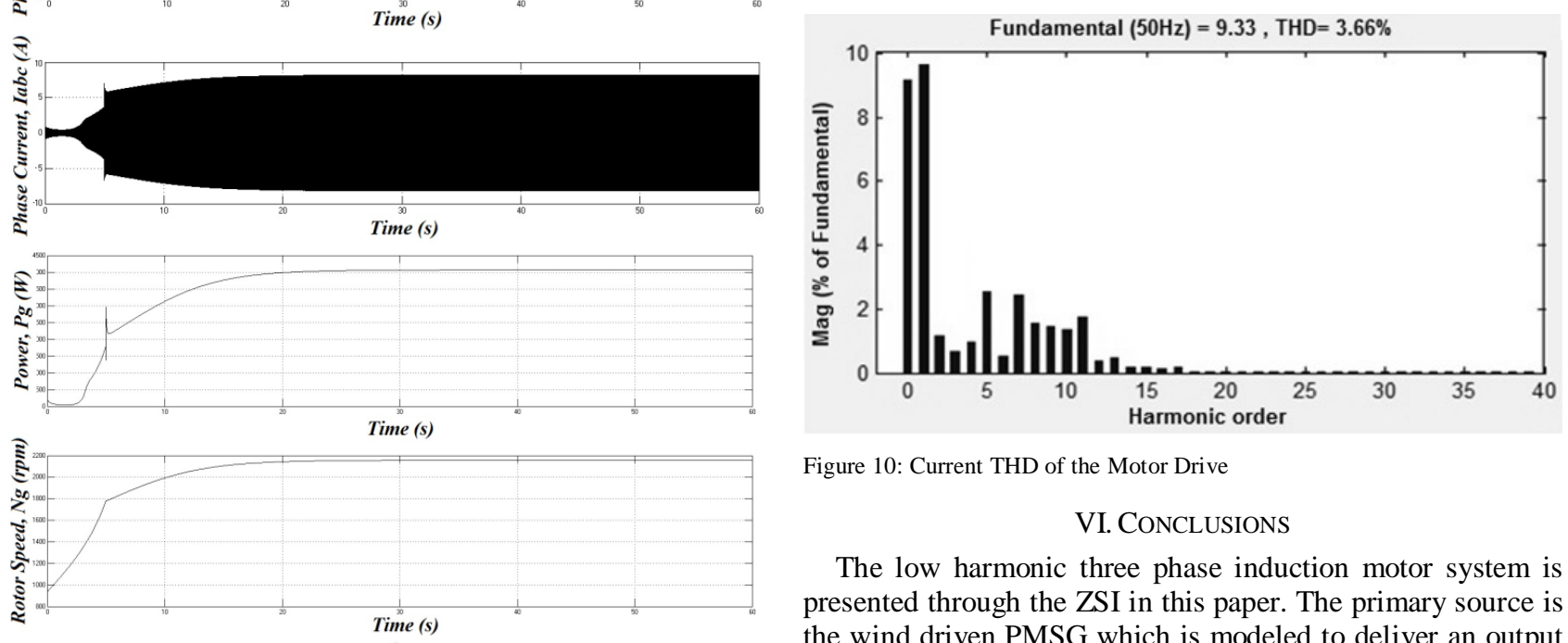

Figure 10: Current THD of the Motor Drive

\section{CONCLUSIONS}

The low harmonic three phase induction motor system is presented through the ZSI in this paper. The primary source is the wind driven PMSG which is modeled to deliver an output power of $4 \mathrm{~kW}$. The induction motor is driven at it rated speed of $1500 \mathrm{rpm}$. The IM is designed for a mechanical power of $5 \mathrm{HP}$ which is when calculated for the efficiency of the system to be $95 \%$. The current harmonics in the drive system obtained is less and under acceptable limits. The designed model is without filter which delivers the current THD of $3.66 \%$. This proposed system is well effective for the standalone application like driving a submersible pump for the rural electrification. With the effectiveness of current harmonic filters the system efficiency can be much more improved in the practical implementation.

\section{CONCLUSIONS}

The low harmonic three phase induction motor system is presented through the ZSI in this paper. The primary source is the wind driven PMSG which is modeled to deliver an output power of $4 \mathrm{~kW}$. The induction motor is driven at it rated speed of $1500 \mathrm{rpm}$. The IM is designed for a mechanical power of $5 \mathrm{HP}$ which is when calculated for the efficiency of the system to be $95 \%$. The current harmonics in the drive system obtained is less and under acceptable limits. The designed model is without filter which delivers the current THD of $3.66 \%$. This proposed system is well effective for the standalone application like driving a submersible pump for the rural electrification. With the effectiveness of current harmonic filters the system efficiency can be much more improved in the practical implementation. 


\section{ACKNOWLEDGMENT}

The author thanks the Director, Dr. N Marie Wilson, Jeppiaar Institute of Technology, Chennai, India for providing technical and financial support for the research work. The author also thanks the Dept. of Electrical and Electronics Engineering, Jeppiaar Institute of Technology for providing a technical support in hardware development.

\section{AUTHOR's BIOGRAPHY}

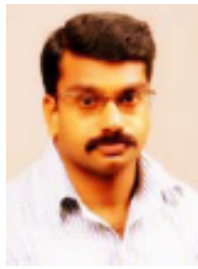

Mr. F. Max Savio was born on Feb 19, 1986 in Hyderabad, India. He received his Bachelor of Engineering in Electrical and Electronics Engineering in 2007 and Masters of Engineering in Power Electronics and Drives in 2013 both from Jeppiaar Engineering College, India under Anna University. He has worked with Essar Projects (India) Limited as Deputy Manager for three years. Currently he is working with Jeppiaar Institute of Technology in the department of Electrical and Electronics Engineering as Assistant Professor. He has published 10 papers in National and International Journals and presented 9 papers in National and Intonations Conferences. His research area includes, Power Electronics, Renewable Energy, Soft switching and Intelligent Controllers.

\section{REFERENCES}

[1] J. F. Conroy and R. Watson, "Low-voltage ride-through of a full converter wind turbine with permanent magnet generator," IET Renew. Power Gener., vol. 1, no. 3, pp. 182-189, Sep. 2007.

[2] J. Y. Dai, D. D. Xu, and B. Wu, "A novel control scheme for current source-converter-based PMSG wind energy conversion systems," IEEE Trans. Power Electron., vol. 24, no. 4, pp. 963-972, Apr. 2009.

[3] K. Amei, Y. Takayasu, T. Ohji, and M. Sakui, "A maximum power control of wind generator system using a permanent magnet synchronous generator and a boost chopper circuit," in Proc. PCC, Osaka, Japan, 2002, vol. 3, pp. 1447-1452.

[4] S. Grabic, N. Celanovic, and V. A. Katic, "Permanent magnet synchronous generator cascade for wind turbine application," IEEE Trans. Power Electron., vol. 23, no. 3, pp. 1136-1142, May 2008.

[5] M. Chinchilla, S. Arnaltes, and J. C. Burgos, "Control of permanent magnet generators applied to variable-speed wind-energy systems connected to the grid," IEEE Trans. Energy Convers., vol. 21, no. 1, pp. 130-135, Mar. 2006.

[6] Z. Chen, J. M. Guerrero, and F. Blaabjerg, "A review of the state of the art of power electronics for wind turbines," IEEE Trans. Power Electron., vol. 24, no. 8, pp. 1859-1875, Aug. 2009.
[7] Klumpner, and F. Blaabjerg, "Modulation method for a multiple drive system based on a two-stage direct power conversion topology with reduced input current ripple," IEEE Trans. on Power Electronics, vol.20, No.3, 2005, pp: 922-929.

[8] Max Savio F. and Sasilumar M., "Space Vector Control Scheme of Three Level ZSI Applied to Wind Energy System," International Journal of Engineering (IJE), Vol 25, No. 4, 2012, pp. 275-282.

[9] Sasikumar M. and Chenthur Pandian S. (2011), 'Modeling and Analysis of Cascaded H-Bridge Inverter for Wind Driven Isolated Self - Excited Induction Generators,' International Journal on Electrical Engineering and Informatics (IJEEI), Vol.3, No. 2, 2011, pp. 132-145.

[10] Sholi Nishikata and Fujio Tatsuta, "A New interconnection Method for Wind Turbine/Generator in a Wind Farm and basic Performances of the Integrated System," IEEE Transactions on Industrial Electronics, vol. 57, no. 2, February 2010. pp. 468-475.

[11] J. M. Carrasco, L. G. Franquelo, J. T. Bialasiewicz, E. Galvan, R. C. P. Guisado, A. M. Prats, J. I. Leon, and N.Moreno-Alfonso," Power Electronic systems for the grid integration of renewable energy sources: A survey," IEEE Transactions of Industrial Electronics, vol. 53, no. 4, Aug. 2006, pp. 1002-1016.

[12] A. Mirecki, X. Roboam, and F. Richardeau, "Architecture complexity and energy efficiency of small wind turbines," IEEE Transactions of Industrial Electronics, vol. 54, no. 1, Feb. 2007,pp. 660-670.

[13] P. Rodriguez, A. V. Timbus, R. Teodorescu, M. Liserre, and F. Blaabjerg, "Flexible active power control of distributed power generation systems during grid faults," IEEE Transactions of Industrial Electronics, vol. 54, no. 5, Oct. 2007, pp. 2583-2592.

[14] J. F. Conroy and R. Watson, "Low-voltage ride-through of a full converter wind turbine with permanent magnet generator," IET Renewable Power Generation, vol. 1, no. 3, Sep. 2007, pp. 182-189.

[15] M. Malinowski, S. Stynski, W. Kolomyjski, and M. P. Kazmierkowski, "Control of three-level PWM converter applied to variable-speed-type turbines," IEEE Transactions of Industrial Electronics, vol. 56, no. 1, Apr. 2009,Jan 2009, pp. 69-77.

[16] J. A. Sayago, T. Bruckner, and S. Bernet, "How to select the system voltage of MV drives - A comparison of semiconductor expenses," IEEE Transactions of Industrial Electronics, vol. 55, no. 9, pp. Sep.2008, 3381-3390

[17] T. Nussbaumer, M. Baumann, and J.W. Kolar, "Comprehensive design of a three-phase three-switch buck-type PWM rectifier," IEEE Transactions of Power Electronics, vol. 22, no. 2, Mar. 2007, pp. 551562.

[18] M. Baumann and J. W. Kolar, "Parallel connection of two three-phase three-switch buck-type unity power-factor rectifier systems with DC link current balancing," IEEE Transactions of Industrial Electronics, vol. 54, no. 6, Dec. 2007, pp. 3042-3053.

[19] Max Savio, Sasikumar M, "A Supervisory Predictive Control using Indirect Matrix Converter for a Variable Speed Wind Energy Conversion System", International Referred Journal of Engineering and Science (IRJES), Vol2, Issue 10, October 2013, pp.39-47. 